\title{
New records of Annonaceae in the Northeast Brazil
}

\author{
Márcio Lucas Bazante`®, Marccus Alves ${ }^{\mathrm{b}}$ \\ a Universidade Federal de Pernambuco, Recife, 50670-901, Pernambuco, Brasil. \\ *mlbazante@gmail.com \\ b Programa de Pós-graduação em Biologia Vegetal, Universidade Federal de Pernambuco, Recife, 50670-901, Pernambuco, Brasil.
}

Received: August 2, 2020 / Accepted: November 8, 2020 / Published online: January 27, 2021

\begin{abstract}
This study reports nine new records of Annonaceae for the states of Alagoas, Ceará, Paraíba and Pernambuco, in Northeastern Brazil: Duguetia lanceolata A.St.-Hil., D. ruboides Maas \& He, D. sooretamae Maas, Guatteria tomentosa Rusby, Hornschuchia bryotrophe Nees, Pseudoxandra lucida R.E.Fr., Trigynaea duckei (R.E.Fr.) R.E.Fr.., Unonopsis guatterioides (A.DC.) R.E.Fr., and Xylopia ochrantha Mart. Descriptions, taxonomical and distributional comments, photos of diagnostic characters, geographic distribution maps and two identification keys, one of the genera of Annonaceae occurring in the Atlantic Forest and Caatinga and another for the new Duguetia records, are provided.
\end{abstract}

Keywords: Atlantic forest, Caatinga, Pseudoxandra, Trigynaea, Unonopsis.

\section{Novos registros de Annonaceae no Nordeste do Brasil}

\begin{abstract}
Resumo
Este estudo reporta nove novos registros de Annonaceae para os estados de Alagoas, Ceará, Paraíba e Pernambuco, nordeste do Brasil: Duguetia lanceolata A. St. -Hil., D. ruboides Maas \& He, D. sooretamae Maas, Guatteria tomentosa Rusby, Hornschuchia bryotrophe Nees, Pseudoxandra lucida R.E.Fr., Trigynaea duckei (R.E.Fr.) R.E.Fr., Unonopsis guatterioides (A.DC.) R.E.Fr., e Xylopia ochrantha Mart. Descrições, comentários taxonômicos e de distribuição, fotos de caracteres diagnósticos, mapas de distribuição geográfica e duas chaves de identificação, uma dos gêneros de Annonaceae ocorrentes na Mata Atlântica e Caatinga e outra dos novos registros de Duguetia, são apresentadas.
\end{abstract}

Palavras-chave: Mata Atlântica, Caatinga, Pseudoxandra, Trigynaea, Unonopsis.

\section{Introdution}

Annonaceae is a pantropical family of flowering plants, with its highest richness and genus-level endemism in the Neotropical region (Doyle \& Le Thomas, 1997; Chatrou, Rainer \& Maas, 2004). It comprises about 2500 species distributed in 109 genera (Rainer \& Chatrou, 2006; Chatrou, Turner, Klitgaard, Maas \& Utteridge, 2018; Chaowasku et al., 2018a, 2018b). In Brazil, approximately 385 species and 30 genera are recorded, most of which occur in lowland tropical wet forest, such as those in the Atlantic Forest domain (Chatrou et al., 2004; BFG, 2018). However, some species of the family also grow in drier areas, as those found in the Caatinga.

The family is characterized as shrubs or trees; with simple, alternate leaves, generally distichous; absence of stipules; trimerous flowers, with one whorl of sepals and two whorls of petals; stamens and carpels usually numerous; and apocarpous to syncarpous fruits (Kessler, 1993). Among Annonaceae genera present in Brazil, Xylopia Aubl. (34 spp.), Duguetia A.St.-Hil. (67 spp.) and Guatteria Ruiz \& Pav. (74 spp.) stand out with higher species richness. In the Northeast, these genera together represent $44 \%$ (49 spp.) of the family (BFG, 2018).
Xylopia (ca. 200 spp.) is the only pantropical genus of the family, identified by the dehiscent fruit with six types of aril morphology, usually forming a complete ring around the micropyle, and the presence of sarcotesta on the seeds in many species, structure unknown in other Annonaceae (Stull et al., 2017; Johnson \& Murray, 2020). Duguetia (95 spp.) presents African and Neotropical species, being recognized by the presence of stellate hairs, scales or both in young twigs, leaves and reproductive organs, and woody-fleshy syncarpous fruits (Maas, Westra \& Chatrou, 2003; Bazante \& Alves. 2017). Guatteria (ca. 180 spp.) is restricted to the Neotropics and recognized by pedicels with suprabasal articulation and apocarpous fruits (Maas et al., 2015; Maas et al. 2019). Like the last one, Pseudoxandra R.E.Fr., Unonopsis R.E.Fr., and Hornschuchia Nees. are also restricted to the Neotropical region. Pseudoxandra (24 spp.) is characterized by leaves with adaxially raised midrib, pedicels with 3-5 bracts, and imbricate petals (Maas \& Westra, 2003). Unonopsis (48 spp.) also presents an adaxially raised midrib, but differs by pedicels with two bracts and valvate petals (Maas, Westra \& Vermeer, 2007). 
Hornschuchia (10 spp.) is restricted to the Atlantic Forest of eastern and southern of the Brazil and identified by flower buds long-conic, linear petals and presence of few stamens (Johnson \& Murray, 1995). Trigynaea Schltdl. (8 spp.) is very similar morphologically to Hornschuchia, but is differentiated by flower buds globose to ovoid, ovate to elliptic petals, and by generally presenting triplinerved leaves at the base (Johnson \& Murray, 1995).

\section{Materials and Methods}

Monthly excursions were carried out between 2016 and 2018 in areas in the Atlantic Forest, Caatinga domains, and in enclaves of Cerrado surrounded by Caatinga, presents in the states of Alagoas, Ceará, Paraíba, Pernambuco and Rio Grande do Norte. However, none of the taxa presented here have been registered for Rio Grande do Norte. Collected samples were processed according to Peixoto \& Maria (2013) and incorporated into UFP herbarium, with duplicates sent to PEUFR. Apart from the field excursions, the following herbarium were analyzed: EAC, EAN, HUEFS, HVASF, IPA, JPB, MAC, PEUFR, UFP, UFRN (acronyms follow Thiers, 2018). Identifications were based on the specialized literature (Dias, 1988; Johnson \& Murray, 1995; Maas \& Westra, 2003; Maas et al., 2003; Maas et al., 2015). Morphological comparisons were conducted with type specimens and images available online at Jstor (https://plants.jstor.org/) and Brazilian Flora (http://reflora.jbrj.gov.br/reflora/herbarioVirtual/).

The morphological descriptions are based on the measurements of the specimens in the study area, following the terminology of Harris \& Harris (2001). They are included here because morphological variations were observed in some new records, better discussed in the topics of taxonomic notes.
In addition, the descriptions provide additional data about a little-known family in Northeast Brazil. Geographic coordinates in decimal degrees and UTM projection were obtained using herbarium material and the SpeciesLink database (http://www.splink.org.br). Maps were prepared using the software QGIS.org (2017).

\section{Results and Discussion}

During a study of the richness of Annonaceae in Northeastern Brazil, we found nine species of the genera presented above that had never been reported to the states of Alagoas, Ceará, Paraíba and Pernambuco: Duguetia lanceolata A.F.C.P., D. ruboides Maas \& He, D. sooretamae Maas, Guatteria tomentosa Rusby, Hornschuchia bryotrophe Nees, Pseudoxandra lucida R. E. Fr., Trigynaea duckei (R. E. Fr.) R. E. Fr., Unonopsis guatterioides (A. DC.) R. E. Fr., and Xylopia ochrantha Mart. Besides that, D. ruboides were recorded for the first time in the Atlantic Forest and Caatinga, and P. lucida for the Atlantic Forest. Based on the importance of documenting species' distributions and their distribution patterns, morphological and ecological profile, in addition to increasing the floristic knowledge for making conservation decisions, we hereby discuss these new records.

As the registration of some genera is extended to the Atlantic Forest and the Caatinga, an updated identification key is presented below with all genera of the family registered in the entire extension of the Atlantic Forest and Caatinga domains.

Key to the genera of Annonaceae from the Atlantic Forest and Caatinga

1. Leaves with adaxially raised midrib 2

2. Pedicels with 3-5 bracts below the articulation, without bracts above it; sepals and petals imbricate; petal margins ciliate. .Pseudoxandra

2'. Pedicels with 1 bract below the articulation, 1 bract above it; sepals and petals valvate; petal margins entire...... 3

3. Stamens with apex of connective tongue-shaped; monocarp stipes $1-2 \mathrm{~mm}$ long..............................Bocageopsis

3'. Stamens with apex of connective discoid; monocarp stipes 3-20 mm long ..................................... Unonopsis

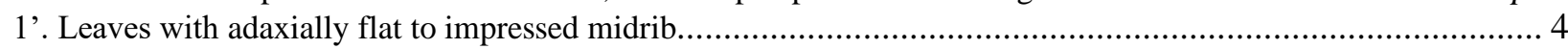

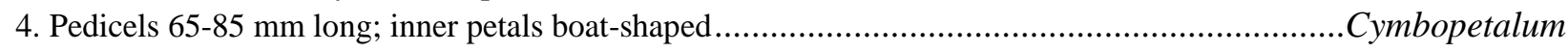

4'. Pedicels 1-65 mm long; inner petals not boat-shaped .................................................................. 5

5. Inner staminodes; free monocarps clavate; seed ruminations irregular ......................................... Anaxagorea

5'. Outer staminodes or absent; free monocarps not clavate or syncarpous; seed ruminations lamelliform, peg-

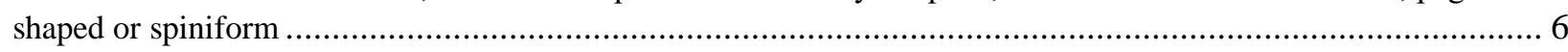

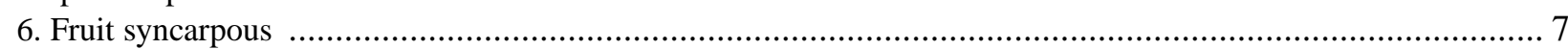

7. Young twigs and leaf blade with scales and/or appressed stellate hairs; coherent monocarps in woody-fleshy

syncarpous fruit...................................................................................................................... Duguetia

7'. Young twigs and leaf blade with simple or stellate-like tufts hairs; fused monocarps in fleshy syncarpous

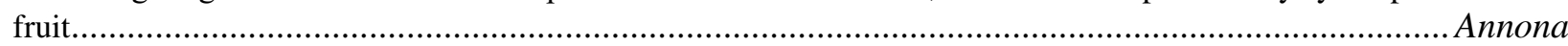

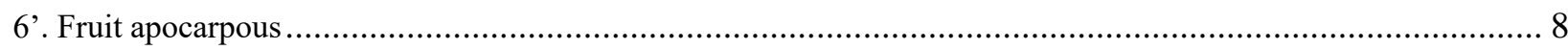

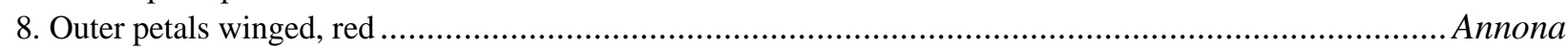

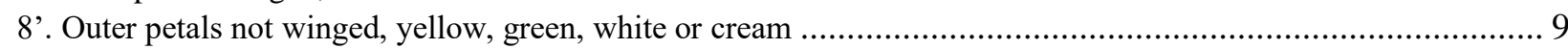

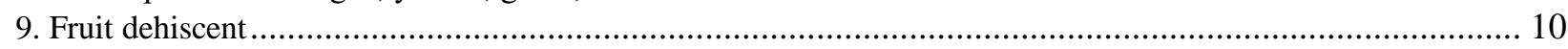

10. Bracts 1-3; staminodes present; monocarps 8-18; seeds arillate ....................................................... Xylopia

$10^{\prime}$. Bracts absent; staminodes absent; monocarps 1-3; seeds carunculate …................................................. 11 
11. Flower buds long-conic; petals linear; stamens 3-18 Hornschuchia

11 '. Flower buds ovoid to globose; petals ovate to elliptic; stamens 45 -numerous Trigyneae

9'. Fruit indehiscent 12

12. Petals margin ciliate

13. Pedicels 1-14 mm long; inflorescence axillary; stamens 10-20; monocarps 1-12............ Oxandra

13'. Pedicels 34-45 mm long; inflorescence leaf-opposed; stamens 40-numerous; monocarps ca. 40 Malmea

12'. Petals margin entire 14

14. Stamens 6-11; apex of connective not discoid

Bocagea

14'. Stamens 20-numerous; apex of connective discoid 15

15. Bracts absent; stamens with apex of connective strongly bilobed; seeds 3-17 per monocarp, rugulose texture

Porcelia

$15^{\prime}$. Bractes 2-5; stamens with apex of connective not bilobed; seeds 1 per monocarp, striate to smooth texture.... 16

16. Flower buds ovoid; bracts 2; hermaphrodite; seeds often pitted to rugose texture...... Guatteria

16'. Flower buds globose; bracts 4-5; androdioecious; seeds striate texture. Ephedranthus

1. Duguetia lanceolata A.F.C.P. de Saint-Hilaire, Fl. Bras. Merid. 1: 35. t. 7. 1825. (Figures 1A-D, 3)

Shrubs to trees $1.5-10.0 \mathrm{~m}$ tall. Young twigs densely covered with stellate scales, adppressed. Leaf blade narrowly elliptic, elliptic, ovate to obovate, $3.5-10.0 \times 1.6-5.0 \mathrm{~cm}$, coriaceous, smooth, margins flat, base cuneate to obtuse, apex attenuate to acuminate; glabrous above, midrib impressed, marginal vein indistinct; sparsely covered with stellate scales below. Inflorescence leaf-opposed, 1-2-flowered; pedicels $0.5-1 \mathrm{~cm}$ long; flower buds broadly ovoid. Sepals basally connate for $2-3 \mathrm{~mm}$, ovate, $0.7-1.0 \times 0.7-0.8 \mathrm{~cm}$. Petals elliptic to narrowly elliptic, $1.5-2.5 \times 0.5-0.6 \mathrm{~cm}$, densely covered with stellate hairs. Fruit syncarpous ,woody-fleshy, globose, 3-4.5 cm diam., basal collar present; fertile carpels ca. 50 , areoles shallowly pyramidal, smooth, glabrous, apicule prominent, erect. Seeds 1 per monocarp, 1,3 x 0,6 cm, ellipsoids to obovoids, brown.

Distribution notes: Duguetia lanceolata is endemic to Brazil and previously described as occurring in the Cerrado and Atlantic Forest domains, in lowland to montane forests from Goiás, in the Central-West region, to Rio Grande do Sul, in the Southern region (Maas, Kamer, Mello-Silva \& Rainer, 2001). The species has been recorded for the Cerrado domain in Ceará, in semideciduous and subperennial forests in elevations of $760 \mathrm{~m}$ (Maas, Maas-Van de Kamer, Mello-Silva \& Rainer, 2001; BFG, 2018). We hereby confirm the occurrence of this species in the Atlantic Forest domain in Pernambuco, in the Caatinga in Alagoas, and in Atlantic Forest enclaves (Brejos de Altitude) and Cerrado vegetation within the Caatinga domain in Ceará and Paraíba.

Taxonomic notes: Several specimens were previously misidentified as $D$. riedeliana $R$.E.Fr, due to the narrowly elliptic leaves and fruits with basal collar present. However, $D$. lanceolata differs by glabrous (vs densely covered with stellate to furcate scales) fruits with smooth areoles (vs verruculose) (see key below) (Maas et al., 2003).

Examined material: BRAZIL. Alagoas: Município de Palmeira dos Índios, Serra Velha (-9.40721, -36.62749), 16 Aug 2001, fr., R.P. Lyra-Lemos \& M.E. Duarte 5774 (HUEFS, MAC). Ceará: Ibiapaba, Jaburuna, Ubajara (-3.85443, 40.92110), 5 Jan 1995, fl., F.S. Araújo 1066 (EAC). Mulungu, Sítio Jardim (-4.28630, -39.01055), fr., 12 Mar 2003, A. Silveira \& R. F. Oliveira 936 (EAC). Guaramiranga, Pendanga
(-4.26332, -38.93310), fr., 13 Oct 2015, A. S. F. Castro 2883 (EAC); idem, (-4.28611, -39.00083), fr., 16 Jan 2003, A. Silveira 556 (EAC); idem, Pendanga, (-4.28630, 39.01055), fl., 20 Oct 2004, V. Gomes et al. 200924 (EAC). Paraíba: Areia, Engenho Cipó, (-7.02253, -36.31512), fl., 30 Jun 2017, E.M. Almeida 2195 (EAN, UFP). Dona Inês, (6.61041, -35.71582), fr., 9 Apr 2008, C.R.F. Xavier 48 (EAN). Pernambuco: São Lourenço da Mata, Estação Ecológica do Tapacurá, (-8.00222, -35.018299), fl., fr., 9 Jan 2001, K. Almeida et al. 99 (JPB).

2. Duguetia ruboides Maas \& He, Bot. Jahrb. Syst. 121: 484. 1999. (Figures 1E-H, 3)

Trees $4 \mathrm{~m}$ tall. Young twigs densely covered with stellate scales, adppressed. Leaf blade narrowly elliptic to lanceolate, 4-8.5 $\times 0.8-2.3 \mathrm{~cm}$, chartaceous, smooth, margins flat, base rounded to obtuse, apex acute to acuminate; glabrous above, midrib impressed, marginal vein indistinct; sparsely covered with stellate scales below. Flowers leaf-opposed to terminal, solitary; pedicels $0.5-1 \mathrm{~cm}$ long; flower buds broadly ovoid. Sepals basally connate for 2-4 mm, broadly ovate, $1-1.4 \times 0.8 \mathrm{~cm}$. Petals ovatetriangular, 1.4-2.2 $\times 1 \mathrm{~cm}$, densely covered with stellate hairs. Fruit syncarpous, woody-fleshy, globose, $2-4 \mathrm{~cm}$ diam., basal collar absent; fertile carpels ca. 50, areoles depressed ovoid, verruculose, densely covered with stellate hairs, minutely apiculate. Seeds 1 per monocarp, 0,5 x 0,5 $\mathrm{cm}$, globose to obovoid, brown.

Distribution notes: Duguetia ruboides is endemic to Brazil and previously believed to be restricted to the Amazon and Cerrado domains in the states of Maranhão, Pará and Piauí (Maas et al., 2003; BFG, 2018). Recently, this species was recorded in Alagoas, but no voucher specimen or reference was cited (BFG, 2018). We could not confirm the occurrence record for Alagoas, but the distribution has now been extended to mountainous areas of the Caatinga in the states of Ceará and Paraíba, and to the Atlantic Forest in Pernambuco.

Taxonomic notes: similarly as D. lanceolata (see taxonomic notes above), many specimens were incorrectly identified as $D$. riedeliana $\mathrm{R}$.E.Fr. The difference in this case is mainly the minutely apiculate (vs sharp-tipped apicule) 
fruits with depressed ovoid areoles (vs pyramidal to trulloid) (see key below) (Maas et al., 2003).

Examined material: BRAZIL. Ceará: Graça (-4.09808, 40.72545), 17 Dec 2007, fl., J.R. Lemos 5 (HUVA). Novo Oriente, Planalto da Ibiapaba (-3.34997, -40.39007), 1991, fl., F.S. Araújo s.n. (IPA 54814); idem, F.S. Araújo 163 (IPA 53478). Chapada da Ibiapaba (-3.55466, -38.84025), 30 Jul 1989, fl., A. Fernandes et al. s.n. (HUEFS 80752). São Gonçalo do Amarante, Pecém (-5.53444, -40.77420), 27 May 2011, fr., R.G. Ferreira 123 (EAC). Paraíba: Monte Horebe (7.23725, -38.25702), 31 May 2012, fr., R.A. Silva et al. 1983 (HVASF). Pernambuco: Gravatá, Engenho Jussara (-8.18332, -35.51724), 6 Jul 2010, fr., L.R. Silva 261 (HST).

3. Duguetia sooretamae Maas, Bot. Jahrb. Syst. 121(4): 486. 1999. (Figures 1I-K, 3)

Trees $6 \mathrm{~m}$ tall. Young twigs densely covered with stellate scales, adppressed. Leaf blade elliptic to narrowly elliptic, 3$13.5 \times 1.5-4.5 \mathrm{~cm}$, coriaceous, smooth, margins flat, base obtuse to acute, apex acuminate to cuneate; glabrous above, midrib impressed, marginal vein indistinct; densely covered with stellate scales below. Flowers leaf-opposed to terminal, solitary; pedicels $1.5 \mathrm{~cm}$ long; flower buds not seen. Sepals basally connate for $3-4 \mathrm{~mm}$, ovate, $2-2.2 \times 1.5-2.2 \mathrm{~cm}$. Petals broadly ovate, $2.5-2.7 \times 2.1-2.5 \mathrm{~cm}$, densely covered with stellate hairs. Fruit syncarpous, woody-fleshy, globose, $2 \mathrm{~cm}$ diam., basal collar present; fertile carpels > 100, areoles shallowly pyramidal, verruculose, densely covered with stellate scales, minutely apiculate. Seeds 1 per monocarp, 0,8 x $0,5 \mathrm{~cm}$, ellipsoids, brown.

Distribution notes: Duguetia sooretamae was considered endemic to the state of Espírito Santo, restricted to a coastal muçununga forest region (forests with sparse tree cover in sandy, wet soils) at Reserva Natural Vale (Maas et al., 2003; BFG, 2018). Here, we present its first record in the Northeast region, in the state of Paraíba, in an area with restinga vegetation in sandy soil.

Taxonomic notes: Maas et al. (2003) already predicted a wider distribution for $D$. sooretamae, with possible occurrences in Ceará and Maranhão. However, the collections from Ceará cited by him (F.S.Araujo IPA 54814, 53478) are recognized as Duguetia ruboides in the present work. D. sooretamae differs by the slightly ridged (vs not ridged) fruit with shallowly pyramidal areoles (vs depressed ovoid) (see key below).

Examined material: BRAZIL. Paraíba: João Pessoa, Mangueira, Rio Cabelo (-6.5022, -34.9769), 12 Feb 2011, fl., E.C.O. Chagas \& M.C. Mota 10177 (MAC); idem, fr., E.C.O Chagas \& M.C. Mota 10178 (MAC); Mataraca, Millennium Inorganic Chemicals Mineração LTDA (6.5022, -34.976), 15 Mar 2012, fl., P.C. Gadelha-Neto 3191 (JPB).

Key to Duguetia species new records morphologically similar to Duguetia riedeliana

1. Leaves coriaceous; petals broadly ovate or elliptic to narrowly elliptic 2

2. Leaves sparsely covered with stellate scales below; petals elliptic to narrowly elliptic; fertile carpels ca. 50; areoles smooth texture, glabrous, proeminent apiculate 1. Duguetia lanceolata 2'. Leaves densely covered with stellate scales below; petals broadly ovate; fertile carpels 100-numerous; areoles verruculose texture, densely covered with stellate scales, minutely apiculate 3. Duguetia sooretamae

1'. Leaves chartaceous; petals ovate-triangular Duguetia riedeliana

3. Fruit with colar basal present; areoles pyramidal to trulloid, sharp-tipped apiculate 2. Duguetia ruboides

4. Guatteria tomentosa Rusby, Bull. New York Bot. Gard. 6(22):504. 1910. (Figures 2A-D, 3)

Shrubs to trees 3-10 m tall. Young twigs densely covered with long-persisting erect, stiff hairs. Leaf blade narrowly elliptic to narrowly oblong, $6-21.3 \times 1.6-4 \mathrm{~cm}$, chartaceous, smooth, margins flat over the whole length, base obtuse, oblique to slightly cordate, apex acuminate; glabrous above, but midrib mostly permanently hairy, flat, marginal vein indistinct; sparsely covered with long-persisting erect, stiff hairs below. Flowers axillary, solitary; pedicels $3.8-6.5 \mathrm{~cm}$ long; flower buds depressed ovoid, slightly pointed. Sepals free, broadly ovate, $0.6-1 \times 0.5-0.8 \mathrm{~cm}$. Petals narrowly ovatetriangular, 1-3.3 $\times 0.5-1 \mathrm{~cm}$, densely covered with apressed hairs. Fruit stipes $0,7-1 \mathrm{~cm}$ long., monocarps and seeds not seen.

Distribution notes: Guatteria tomentosa occurs from Central America to Southeast Brazil, almost covering the whole distribitional range. In Brazil, this species was earlier reported from the Amazon and Atlantic Forest domains in the states of Acre, Amazonas, Bahia, Espírito Santo, and Minas
Gerais in lowland, restinga, submontane and montane forests. (Maas et al., 2015; BFG, 2018). Here, it is first reported in Alagoas, from a collection in ombrophilous forest with clayey and sandy soil.

Taxonomic notes: The only voucher with fruit does not have monocarps, preventing its description. This species can be recognized for its long-persisting indument of erect, stiff hairs throughout the plant, pedicels $3.8-6.5 \mathrm{~cm}$ long, and by flower buds slightly pointed (Maas et al., 2015). The material examined in Alagoas presents some variations according to the description by Maas et al. (2015), with leaves sparsely covered with hairs below (vs densely covered with hairs below), and basal margins flat (vs. often revolute).

Several specimens were previously misidentified as $G$. australis A.St.-Hil., due to the narrowly elliptic leaves and long pedicels. However, G. tomentosa differs mainly by its erect hairs all over the plant (vs adppressed hairs), and leaf base obtuse, oblique to slightly cordate (vs acute to attenuate) (Maas et al., 2015). G. tomentosa is also very similar to Guatteria villosissima A.St.-Hil., but from that species it differs by its leaf margins revolute at the base only 
or flat (vs revolute over the whole length), pedicels $0.5-7 \mathrm{~cm}$ long (vs $0.5-2 \mathrm{~cm}$ long), flower buds slightly pointed (vs. not pointed), and stipes of monocarp 0.4-2 cm long (vs 0.3-0.4 cm long). It can also be confused with G. hirsuta Ruiz \& Pav., distinguished by its only erect hair all over the plant (vs erect and appressed hairs), and by flower buds slightly pointed (vs not pointed) (Maas et al., 2015).

Examined material: BRAZIL. Alagoas: Ibateguara, Murici, Serra do Ouro (9.216667, -33.83333), 4 Nov 2003, fl., A.I.L. Pinheiro 99 (MAC); idem, Serra da Bananeira, 6 Jan 2005, fl., Mendonça 366 (MAC); idem, Mata do Poço Danta (-35.87250, -9.21194), 10 Feb 2009, fl., A. Alves-Araújo et al. 1131 (UFP). Taquara, Engenho Dois Abraços $\quad(-9.64500,-36.49720), 16$ Dec 2003, fl., M. Oliveira \& A.A. Grillo 1516 (UFP).

\section{Hornschuchia bryotrophe Nees, Flora 4: 302. 1821. (Figures 2E-H, 3)}

Shrubs $2.5 \mathrm{~m}$ tall. Young twigs pilose, adppressed hairs. Leaf blade oblanceolate, 4-16-28 × 5.8-9 cm, chartaceous, smooth, margins flat, base narrowly oblique, apex acuminate; glabrous above, midrib impressed, marginal vein distinct; sparsely covered with simple, appressed hairs below. Inflorescence flagelliform, 1-3-flowered, branches ca. $1 \mathrm{~m}$ long; pedicels $0.3-1.7 \mathrm{~cm}$ long; flower buds long-conic. Sepals totally connate, cup-shaped, $2-3 \mathrm{~mm}$ long. Petals linear, $1.5-$ $2.0 \times 0.3-0.6 \mathrm{~cm}$, densely simple, appressed hairs. Fruit apocarpous, dehiscent; monocarps 1-3, fusiform, 4-5.5 × 0.9$1 \mathrm{~cm}$, smooth, pubescent, minutely apiculate, stipes $0.5-1.5 \mathrm{~cm}$ long. Seeds 5-10 per monocarp, $1,3 \times 0,5 \mathrm{~cm}$, oblongellipsoids, brown, carunculate.

Distribution notes: Hornschuchia bryotrophe is endemic to Brazil and the most widely distributed species of the genus, with records from Bahia, Espírito Santo, Minas Gerais and Rio de Janeiro, in wet forest and sometimes on sandy soils (Johnson \& Murray, 1995; BFG, 2018). It is now also recorded in Atlantic Forest remnants in Pernambuco, close to the coast, as most of the records of this species.

Taxonomic notes: It is distinguished from other species by its narrowly oblique leaf base, distinctly impressed marginal vein, and flowers arranged in flagelliform branches (Johnson \& Murray, 1995).

Examined material: BRAZIL. Pernambuco: Ipojuca, Engenho da Conceição Velha, mata das Três Passagens (8.45775, -35.23751), 9 Dec 1997, fl., fr., S. Tavares et al. 51 (IPA, JPB, PEUFR, UFP).

6. Pseudoxandra lucida R.E.Fr., Acta Horti Bergiani 12: 230, f. 3a-e. 1937. (Figures 3, 4A-D)

Shrubs $2.0 \mathrm{~m}$ tall. Young twigs glabrous. Leaf blade narrowly oblong-elliptic, 7.0-13.5 × 1.8-3.0 cm, coriaceous, densely verruculose, margins flat, base obtuse to acute, sometimes with weak angular projections on both sides, apex acuminate; glabrous above, shiny, midrib raised, marginal vein distinct; glabrous below. Inflorescence on older branches, 1-2flowered; pedicels 10-12 mm long; flower buds not seen. Sepals free, broadly triangular, $0.2 \times 0.4 \mathrm{~cm}$. Petals not seen. Fruit apocarpous, indehiscent; monocarps $7-8$, globose, 1.1-
$1.2 \mathrm{~cm}$ diam., wall ca. $0.2 \mathrm{~mm}$ thick, smooth surface in sicco, glabrous, minutely apiculate; stipes $1.5 \mathrm{~cm}$ long. Seeds 1 per monocarp, 0.8-0.9 × 0.8-0.9 cm, sub-globose, reddishbrown.

Distribution notes: Pseudoxandra lucida was previously reported throughout the Amazon region in Brazil and Guyana, in lowland forests in elevations up to $250 \mathrm{~m}$ (Maas \& Westra, 2003; BFG, 2018). It is registered here for the first time in the Atlantic Forest domain of Northeastern Brazil, from a collection in the state of Alagoas. The specimen was collected in dense montane ombrophilous forest, at elevation between 380-400 m.

Taxonomic notes: The species richness of Pseudoxandra grew considerably throughout the taxonomic treatments (Fries, 1937; Maas, Heusden, Koek-Noorman, van Setten \& Westra, 1986; Maas \& Westra, 2003). As a result, complexes of similar species morphologically need to be further analyzed, as is the case of P. lucida and Pseudoxandra polyphleba (Diels) R.E.Fr. They share leaves densely to rather densely verruculose, glabrous, distance of marginal vein from margin 1-2 mm, and monocarps globose, with thin wall. But they differ mainly by the flowers, being larger and hairy in P. lucida, and small and glabrous in P. polyphleba (Maas \& Westra, 2003). However, as in most collections of this genus, the only specimen collected in the study area does not have flowers. Thus, the voucher was identified as $P$. lucida by the coriaceous leaves (vs chartaceous), shiny above (vs not shiny), and monocarps with smooth surface in sicco (vs often shrivelled surface in sicco) (Maas \& Westra, 2003).

Furthermore, $P$. lucida resembles Pseudoxandra bahiensis Mass, which is endemic to Bahia, by the narrowly oblong-elliptic, densely verruculose leaves, with the leaf base sometimes presenting angular projections, and globose monocarps. The main difference between the two species is the thinner fruit wall, ca. $0.2 \mathrm{~mm}$ thick (vs $1.2-1.8 \mathrm{~mm}$ ). The new record is also highly variable and slightly aberrant due to the long stipes, which usually are $4-10 \mathrm{~mm}$ long, being more similar to collections from Peru and Colombia (Maas \& Westra, 2003) but fits with respect to all other characteristics.

Examined material: BRAZIL. Alagoas: Ibateguara, Coimbra, Grota da Burra (-8.95294, -35.97049), 29 Mar 2011, fr., E. Chagas-Mota 10645 (MAC).

\section{Trigynaea duckei (R.E.Fr.) R.E.Fr., Arkiv för Botanik} 33A: 14. 1946. (Figures 3, 4E-H)

Treelets $1.5-3 \mathrm{~m}$ tall. Young twigs sparsely pilose to glabrous, adppressed hairs. Leaf blade elliptic, narrowly elliptic to narrowly obovate, $6.7-11.2 \times 2.2-4.6 \mathrm{~cm}$, chartaceous, smooth, margins flat, base cuneate, occasionally inequilateral, apex acuminate; glabrous above, midrib plane slightly impressed; sparsely simple, appressed hairs; secondary and higher-order veins slightly raised on both surfaces, triplinerved at the base. Flowers internodal, solitary; pedicels 2-5 mm long; flower buds not seen. Sepals connate, shallowly cup-shaped, 3-4 mm long, lobes depressed-triangular to indistinct, persistent on the fruit. Petals not seen. 

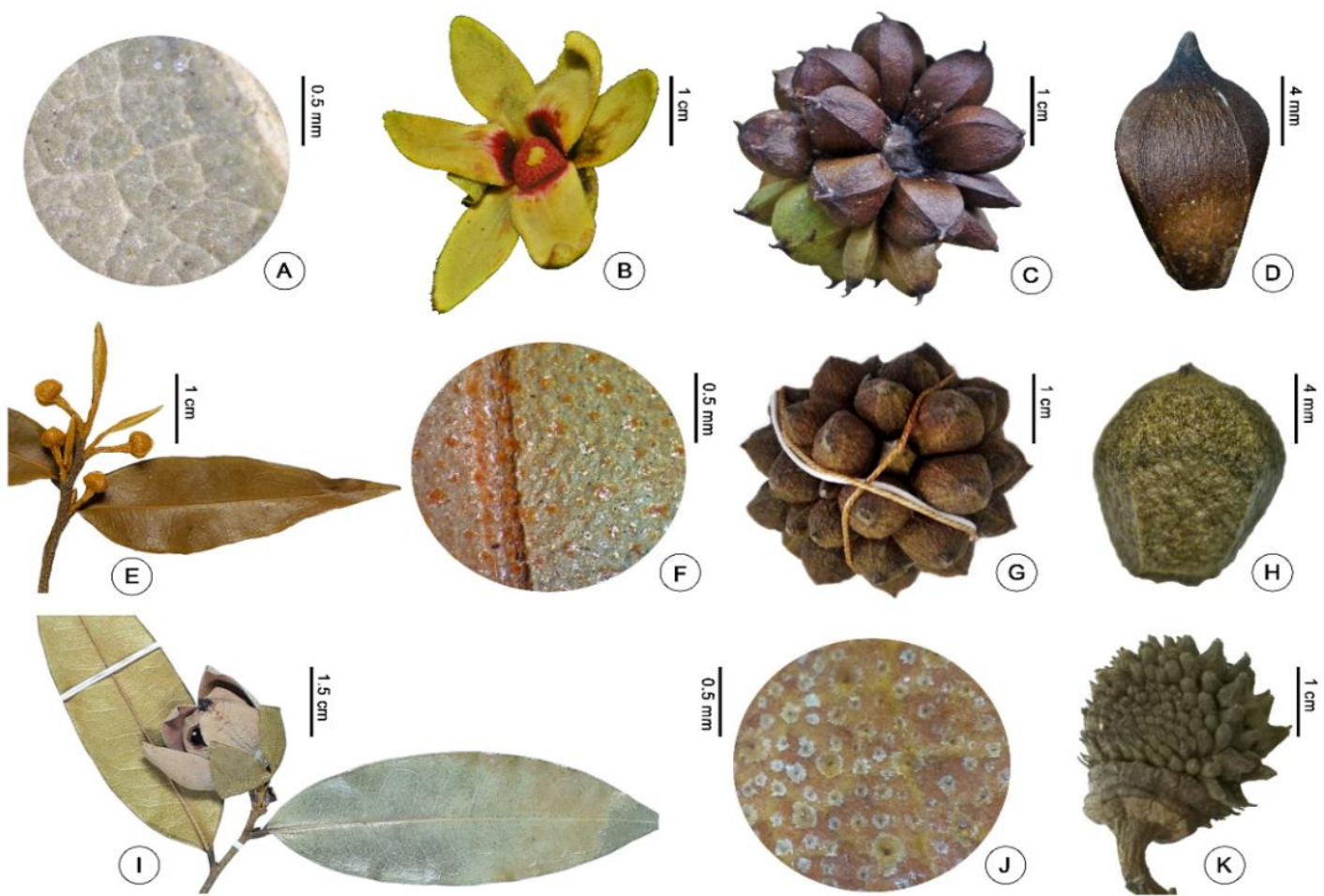

Figure 1. Diagnostic characters of the new records in Annonaceae. A-D. Duguetia lanceolata: A. Indumentum at the lower side of the leaf; B. Flower; C. Fruit; D. Monocarp; from E.M. Almeida 2195 (EAN, UFP). E-H. Duguetia ruboides: E. Branch with flower buds; F. Indumentum at the lower side of the leaf; G. Fruit; H. Monocarp; from R.G. Ferreira 123 (EAC), F.S. Araújo 512 (EAC). I-K. Duguetia sooretamae: I. Branch with flower; J. Indumentum at the lower side of the leaf; K. Fruit; from E.C.O. Chagas \& M.C. Mota 10177 (MAC), E.C.O. Chagas \& M.C. Mota 10178 (MAC).
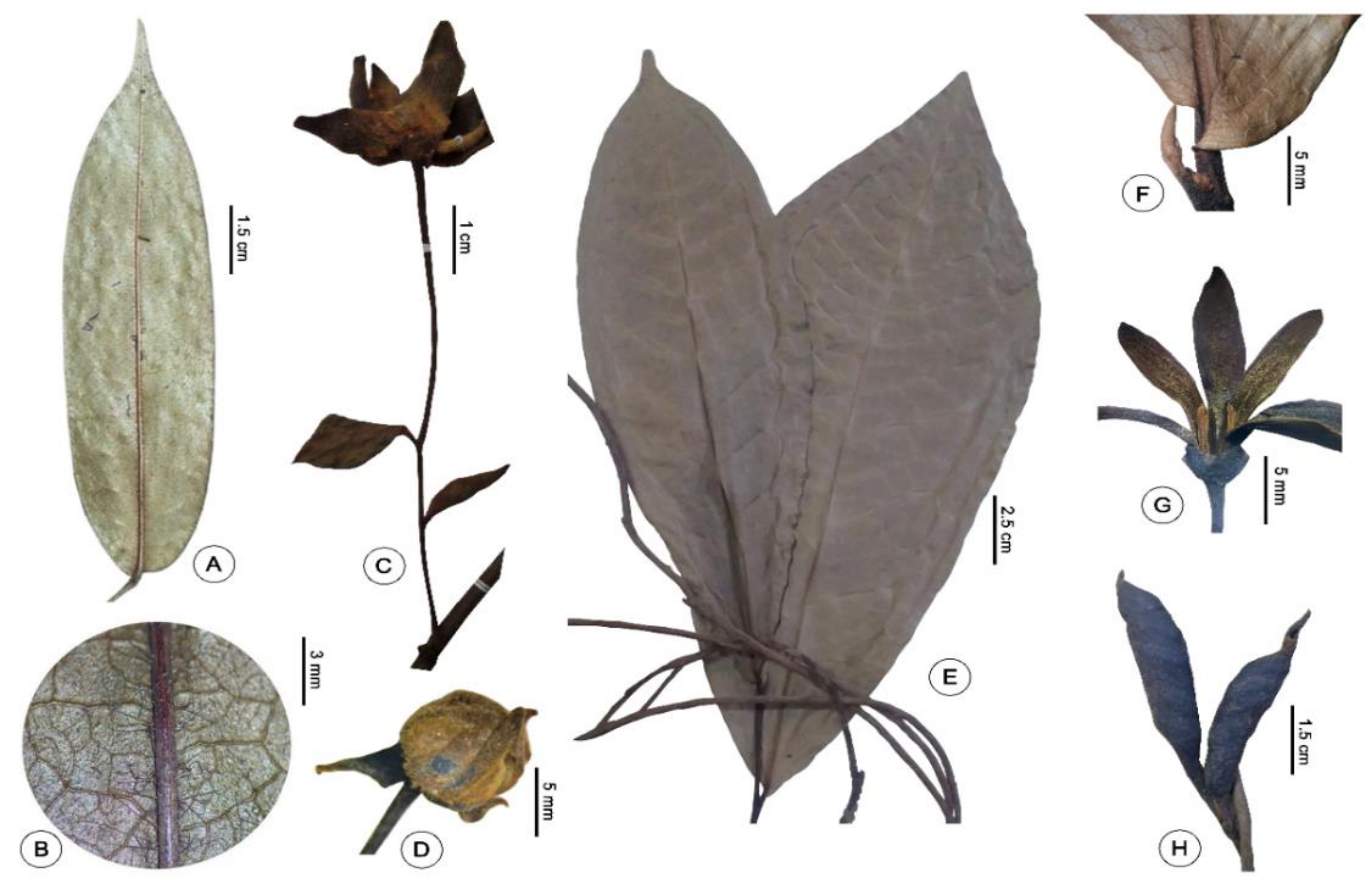

Figure 2. Diagnostic characters of the new records in Annonaceae. A-D. Guatteria tomentosa: A. Lower side of the leaf; B. Detail of the indumentum at the lower side of the leaf; C. Flower with long pedicel; D. Flower bud; from N.T. Mendonça 366 (MAC), M. Oliveira \& A.A. Grillo 1516 (IPA). E-H. Hornschuchia bryotrophe: E. Upper side of the leaves with part of inflorescence; F. Leaf base; G. Flower; H. Fruit; from S. Tavares et al. 51 (IPA, JPB, PEUFR, UFP). 


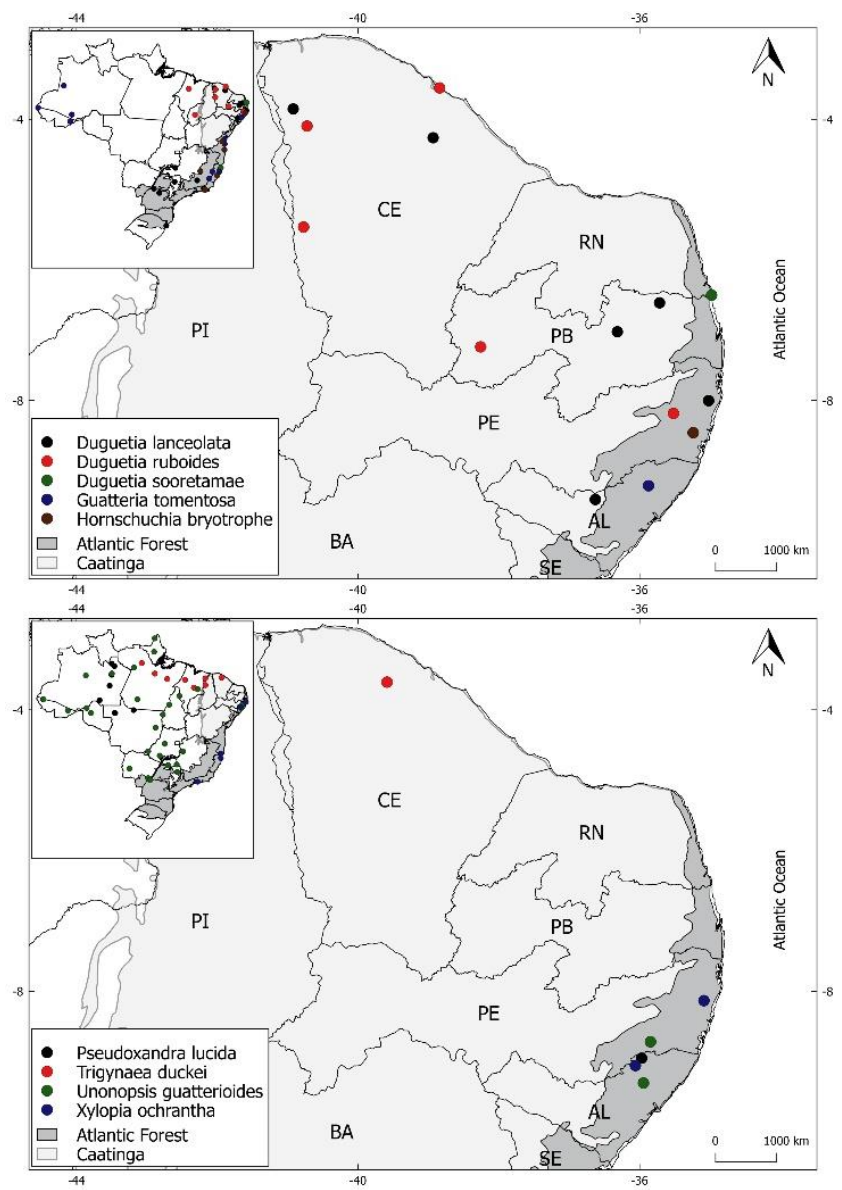

Figure 3. Map showing the location of the new records in Annonaceae in the northeastern Brazil. Legend: $\mathrm{AL}=$ Alagoas; $\mathrm{BA}=$ Bahia $; \mathrm{CE}=$ Ceará; $\mathrm{PB}=$ Paraíba $; \mathrm{PE}=$ Pernambuco PI = Piauí; $\mathrm{RN}=$ Rio Grande do Norte $\mathrm{SE}=$ Sergipe.

Fruit apocarpous, dehiscence not seen; pedicels $2-5 \mathrm{~mm}$ long; monocarps 2-6, rounded-ovoid, 0.7-0.8 $\times 0.5-0.6 \mathrm{~cm}$, wall 0.9-1.6 mm thick, finely warty, velutinous, sulcate on one side, umbonate, apiculate, sessile. Seeds ca. 3-4 per monocarp, destroyed.

Distribution notes: Trigynaea duckei is the species with the widest and most discontinuous distribution of the genus (Johnson \& Murray, 1995; Lobão, 2017). It occurs in the Amazon and Caatinga domains of north and northeast of Brazil, in the states of Pará, Maranhão and Piauí, and then into Venezuela, Ecuador, Peru and Bolivia, in elevations between 60-1500 m (Johnson \& Murray, 1995; BFG, 2018). The occurrence of this species in the state of Ceará is hereby confirmed. The specimen was collected in the interior of the Serra de Uruburetama forest, which is considered a 'Brejo de altitude' (Atlantic Forest remnants in higher elevations in the caatinga), with elevation of $928 \mathrm{~m}$.

Taxonomic notes: Only a single voucher of this specimen was found in the study area, without flowers, with young fruits and seeds destroyed by insects, which made identification difficult. In addition, the voucher has morphological differences based on the literature (Johnson \& Murray, 1995), such as the presence of 2-6 monocarps per fruit (vs 1-2), sessile (vs stipes 1.5-6 mm long), and 3-4 seeds per monocarp (vs 611). However, the specimen was recognized as Trigynaea duckei by leaves surface smooth, distinctly triplinerved, midrib flat above, internodal and apocarpous fruits with pedicel 2-5 mm long, calyx persistent into a cup-shaped, and monocarps finely warty.Trigynea, Bocagea A.St.-Hil. and Hornschuchia Nees form a clade within the Bocageeae tribe, and show some similarities as the sepals persistent on fruit, low numbers of stamens, and small torus diameter (Johnson $\&$ Murray, 1995). Among these two genera, Trigynaea is more similar to Hornschuchia for sharing small flowers with connate sepals and carunculate seeds. Considering the ten species of Hornschuchia, T. duckei is more similar to $H$. lianarum D. M. Johnson by fruiting pedicels $2-5 \mathrm{~mm}$ long, monocarps globose to ellipsoid and sessile (Johnson \& Murray, 1995). It differs from that species by elliptic to narrowly-obovate leaves (vs ovate to broadly ovate), distinctly triplinerved (not triplinerved), monocarps apex umbonate (vs rounded) and finely warty (vs rugose).

Examined material: BRAZIL. Ceará: Uruburetama, Virada da Serra (-3.60527, -39.58777), 14 Nov 2016, fr., A.M.S. Santos et al. 03 (EAN).

8. Unonopsis guatterioides (A.DC.) R.E. Acta Horti Berg. 12: 241. 1937. (Figures 3, 5A)

Trees 7-8 $\mathrm{m}$ tall. Young twigs pubescent, erect to adppressed hairs. Leaf blade narrowly elliptic to narrowly obovate, $8.5-21 \times 3.5-8.2 \mathrm{~cm}$, chartaceous, densely verruculose, base obtuse to acute, apex acuminate; midrib erect-pubescent above, raised, marginal vein distintic; midrib and secondary veins with densely simple, erect to appressed hairs below. Inflorescence on older branches, 12-flowered; pedicels 12-16 mm long; flower buds not seen. Sepals free, broadly triangular, $0.2 \times 0.3 \mathrm{~cm}$. Petals not seen. Fruit apocarpous, indehiscent; monocarps 3-15, ellipsoid to globose, 2-2.3 $\times 1.6-2.3 \mathrm{~cm}$, wall thickness not measured, smooth, sparsely pilose, minutely apiculate; stipes $1.5-2 \mathrm{~cm}$ long. Seeds not seen.

Distribution notes: Unonopsis guatterioides has a wide distribution in the Amazon region of South America. It also occurs in other Brazilian regions, in the Amazon, Cerrado and Atlantic Forest domains (Maas et al. 2007). We hereby present the first record of the genus for the states of Alagoas and Pernambuco, collected in submontane ombrophilous forests, in elevations of 150-750 m.

Taxonomic notes: According to Maas et al (2007), Unonopsis guatterioides is the most variable species in the genus, being distinguished mainly by the small flowers and 1-6-seeded monocarps. However, like the two species presented above, the few vouchers in the study area do not have flowers, and unfortunately it was not possible to open some monocarps to measure the thickness of the wall and analyze the seeds, important characters in the genus. Despite this, among the seven species of the genus registered in the Atlantic Forest (BFG, 2018), the exsiccates were determined to be $U$. guatterioides because it differs from $U$. bahiensis Maas \& Orava by the chartaceous leaves (vs coriaceous); from $U$. renati Maas \& Westra by the ellipsoid to globose monocarps (vs only globose) and stipes $1.5-2 \mathrm{~cm}$ long (vs $0.3-0.5 \mathrm{~cm}$ long); and from U. aurantiaca Maas \& Westra, $U$. bauxitae Maas, Westra \& Mello-Silva, U. riedeliana 
R.E.Fr, and U. sanctae-teresae Maas \& Westra by the erect to adppressed hairs in the twig branches (vs only adppressed) and leaves with adaxially pilose to pubescent midrib (vs glabrous) (Maas et al. 2007).

Examined material: BRAZIL. Alagoas: Murici, Estação
Ecológica de Murici, Fazenda Santa Fé (-9.30666, 35.94332), 6 Jul 2012, fr., M.C.S.Mota, E.C.O. Chagas \& J.W.A. Silva 11746 (MAC). Pernambuco: Jaqueira, RPPN Frei Caneca, Mata do Quengo, interior da Mata Atlântica (8.7197, -35.8439), 31 May 2012, sterile, B.S.Amorim et al. 1608 (UFP, NY).
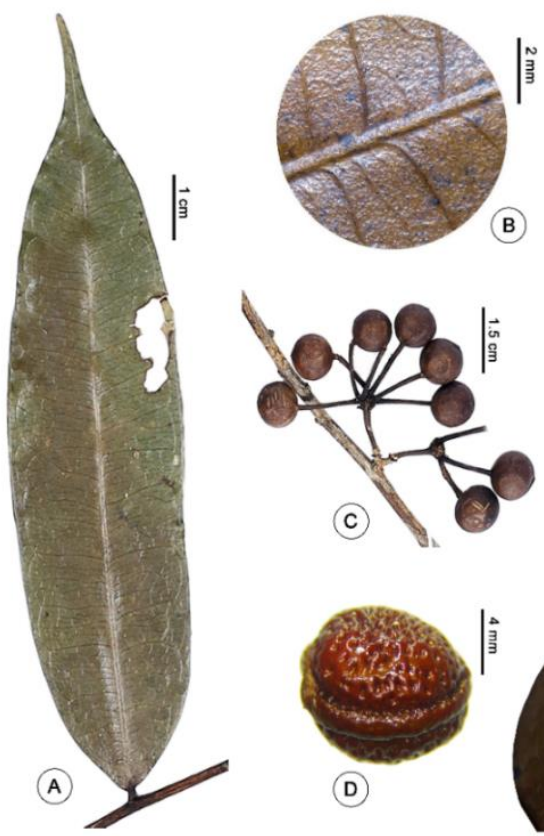

F
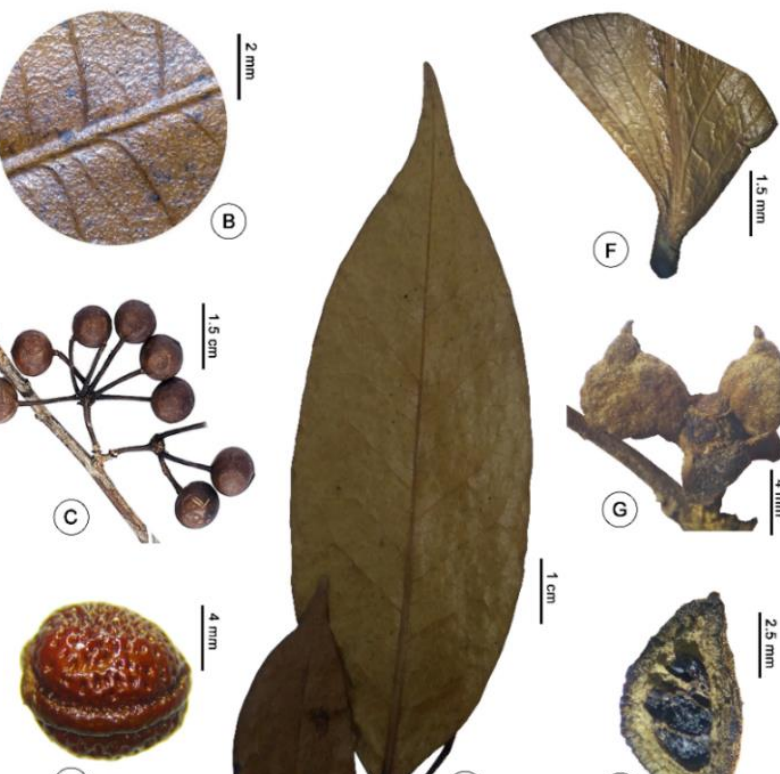

(D)
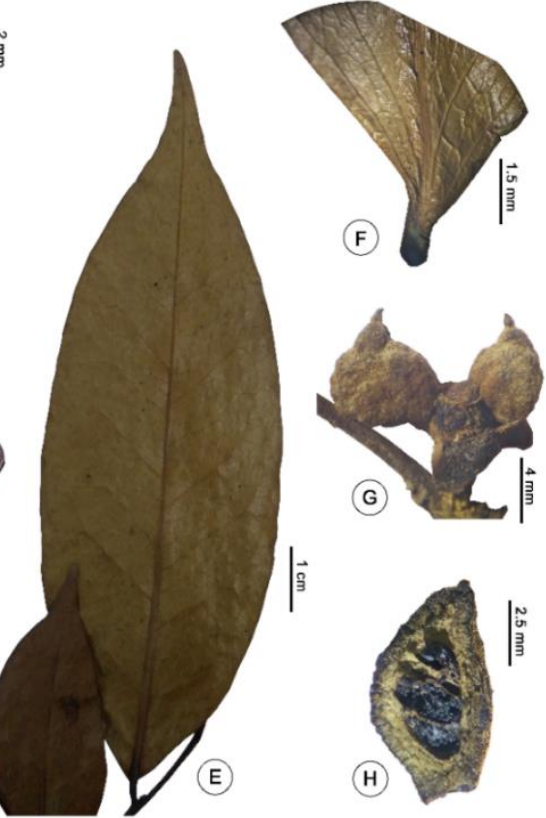

Figure 4. Diagnostic characters of the new records in Annonaceae. A-D. Pseudoxandra lucida: A. Upper side of the leaf; B. Detail of the upper side of the leaf verruculose; C. Fruit; D. Seed; from E.C.O. Chagas \& M.C. Mota 10645 (MAC). E-H. Trigynaea duckei: E. Lower side of the leaves; F. Leaf base; G. Fruit; H. Longitudinal cut of the monocarp; from A.M.S. Santos et al. $03(\mathrm{EAN})$.
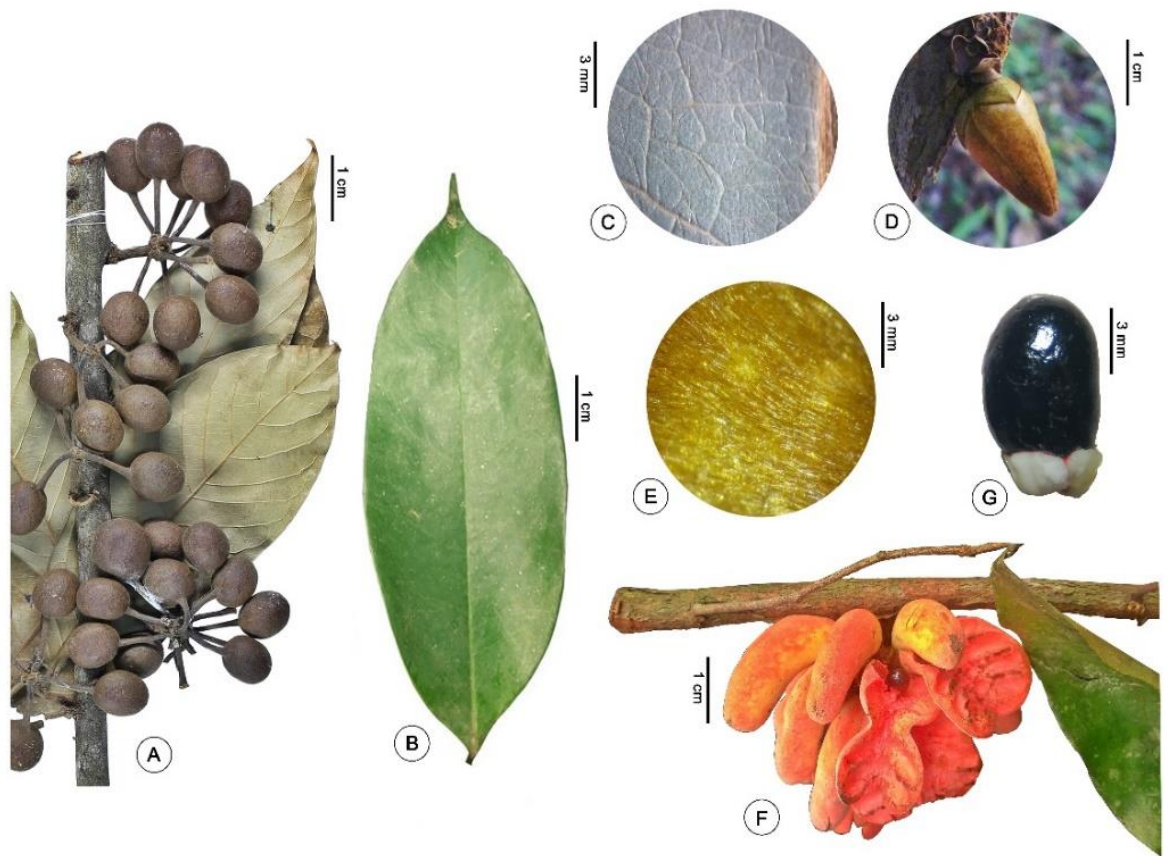

Figure 5. Diagnostic characters of the new records in Annonaceae. A. Unonopsis guatterioides: Branch with fruits; M.C.S.Mota, E.C.O. Chagas \& J.W.A. Silva 11746 (MAC). B-G. Xylopia ochrantha: B. Upper side of the leaf; C. Indumentum at the lower side of the leaf; D. Flower; E. Indumentum at the lower side of the petal; F. Fruit; G. Seed; from N.K. Luna et al. 271 (UFP), M.L. Bazante \& M. Alves 1095 (UFP). 
9. Xylopia ochrantha Mart., Fl. Bras. 13(1): 43. 1841. (Figures 3, 5B-G)

Trees 8-9 $\mathrm{m}$ tall. Young twigs with densely simple, appressed hairs, elliptic, subcoriaceous, smooth, margins flat, base acute, apex acuminate; glabrous above, midrib impressed, marginal vein indistinct; simple, adpressed hairs below. Inflorescence cauliflorous, 1-15-flowered; pedicels $5 \mathrm{~mm}$ long; flower buds broadly ovoid. Sepals basally connate for 2 $3 \mathrm{~mm}$, broadly ovate, $6 \times 6-7 \mathrm{~mm}$ long. Petals ovate-triangular to trulate, $1-2 \times 0.5-0.8 \mathrm{~cm}$, with densely adppressed hairs. Fruit apocarpous, dehiscent; monocarps ca. 10, falcate, 3-3.7 x $1.1 \mathrm{~cm}$, smooth, with densely adppressed hairs, minutely apiculate; stipes $1-1.4 \mathrm{~cm}$ long. Seeds $6-8$ per monocarp, $1 \mathrm{x}$ $0.6 \mathrm{~cm}$, ellipsoid, dark to brown; arils bilobed, white.

Distribution notes: Xylopia ochrantha is endemic to Brazil and described as restricted to areas of restinga and ombrophilous forests in Bahia, Espírito Santo and Rio de Janeiro (Dias, 1988; BFG, 2018). According to BFG (2018), this species possibly occurs in Pernambuco, but no voucher or reference is cited. Here, we expand the geographic distribution of the species to the states of Alagoas and Pernambuco. It was collected in dense ombrophilous forest fragments and subperennial forests.

Taxonomic notes: This species is well defined by its cauliflory, a rare characteristic in Xylopia species in the Atlantic Forest, and by the dense indument of golden hairs in flowers and fruits (Dias, 1988). Only one other species of Xylopia presents cauliflory in the Atlantic Forest and Caatinga domains, $X$. decorticans Johnson \& Lobão, which differs from $X$. ochrantha by the flaking bark in the twig branches and considerably larger leaves (9-24 cm long) (Lobão \& Johnson, 2007; BFG, 2018).

Examined material: BRAZIL. Alagoas: Ibateguara, Coimbra, Grota do Varjão (-8.96920, -35.95153), 13 Dec 2001, fl., M. Oliveira \& A. Grilo 664 (UFP, UFRN, MAC). Pernambuco: Moreno, Reserva Ecológica de Carnijó (8.13470, -35.08510), 24 Apr 2003, fl., C.F.R. Ferreira et al. 81 (IPA). Cabo de Santo Agostinho, Engenho Boa Vista (8.29662, -34.99826), 13 Mar 1996, fl., D.R. Siqueira et al. 156 (PEUFR). Sirinhaém, Mata de Jaguaré (-8.59405, -35.18207), 18 May 2016, fl., N.K. Luna et al. 271 (UFP); idem, Trapiche, Mata das Cobras ( -9.03331,-37.68015), s.d., fr., M.L. Bazante \& M. Alves 1095 (UFP).

\section{Conclusion}

According to the recent literature, 37 species of Annonaceae are recorded in the concerned states, with 23 species in Alagoas and Pernambuco, 20 in Ceará, and 18 in Paraíba. Duguetia, Guatteria and Xylopia were previously recorded in these states, unlike the other genera presented here (Pontes, Barbosa \& Maas, 2004; Lyra-Lemos, Mota, Chagas \& Silva, 2010; Nusbaumer et al., 2015; Bazante \& Alves, 2017; BFG, 2018). According to our results, the diversity of Annonaceae is expanded in these states, now presenting 28 species in Alagoas and Pernambuco, 22 in Ceará, and 21 in Paraíba. Additionally, we present the first record of the genus Trigynaea in Ceará, Hornschuchia and Unonopsis in Pernambuco, and Pseudoxandra and Unonopsis in Alagoas.
With the exception of Guatteria tomentosa, Pseudoxandra lucida, Trigynaea duckei and Unonopsis guatterioides, all other new records are endemic to Brazil. Furthermore, we present the first record of P. lucida in the Atlantic Forest domain of Northeastern Brazil, and of Duguetia ruboides for the Caatinga and Atlantic Forest domains. These new records support a previously detected Amazonian-Atlantic Forest disjunction, with relicts of that connection through the Brejos de Altitude in the Brazilian Northeast (Andrade-Lima, 1953; Rizzini, 1963). Expanding the geographical distribution of Annonaceae species in the Northeast of Brasil helps to update information on endemism patterns, morphological characteristics and conservation status, all of which are essential in the creation of measures for species preservation and management (Mace, 2004). Thus, the new records presented here improve our understanding of the flora of Northeastern Brazil and they also reinforce the importance of keeping the collections up to date, since many identification errors were found and, as a result of this work, important contributions to the knowledge of these species are presented here. In addition, it also demonstrates the importance of better collection efforts in the Caatinga and Atlantic Forest remnants in the region, due to the fragmented and under-sampled vegetation.

\section{Acknowledgements}

We thank the Conselho Nacional de Desenvolvimento Científico e Tecnológico (CNPq) for the granted scholarship, the curators of visited herbaria, Carolina Siniscalchi for English review, and Francione Gomes-Silva for elaborating maps.

\section{References}

Andrade-Lima, D. (1953). Notas sobre a dispersão de algumas espécies vegetais no Brasil. Anais da Sociedade de Biologia de Pernambuco, 11, 25-49.

Bazante, M., \& Alves, M. (2017). A new species of Duguetia (Annonaceae) from the Atlantic Forest of northeastern Brazil. Phytotaxa, 314(2): 266272. doi: $10.11646 /$ phytotaxa.314.2.8

BFG. (2018). Brazilian Flora 2020: innovation and collaboration to meet Target 1 of the Global Strategy for Plant Conservation (GSPC). Rodriguésia, 69, 1513-1527. doi: 10.1590/2175-7860201869402

Chaowasku, T., Damthongdee, A., Jongsook, H., Ngo, D. T., Le, H. T., Tran, D. M. \& Suddee, S. (2018a). Enlarging the monotypic Monocarpieae (Annonaceae, Malmeoideae): recognition of a second genus from Vietnam informed by morphology and molecular phylogenetics. Candollea, 73(2), 261-275. doi: 10.15553/c2018v732a11

Chaowasku, T., Damthongdee, A., Jongsook, H., Nuraliev, M. S., Ngo, D. T., Le, H. T., Lithanatudom, P., Osathanunkul, M., Deroin, T., Xue, B. \& Wipasa, J. (2018b). Genus Huberantha (Annonaceae) Revisited: Erection of Polyalthiopsis, a New Genus for H. floribunda, with a New Combination H. luensis. Annales Botanici Fennici, 55(1-3), 121-136. doi: $10.5735 / 085.055 .0114$

Chatrou, L. W., Rainer, H., \& Maas, P. J. M. (2004). Annonaceae. In Smith, N., Mori, S. A., Henderson, A., Stevenson, D. W., \& Heald, S. V. (Ed.), Flowering plants of the Neotropics (pp. 18-20). Princenton University Press, New Jersey.

Chatrou, L. W., Turner, I. M., Klitgaard, B. B., Maas, P. J., \& Utteridge, T. M. (2018). A linear sequence to facilitate curation of herbarium specimens of Annonaceae. Kew bulletin, 73(3), 39. doi: $10.1007 / \mathrm{s} 12225-018-9764-3$

Dias, M. C. (1988). Estudos taxonômicos do gênero Xylopia L. 
(Annonaceae) no Brasil extra-amazônico. Dissertação de Mestrado. Universidade Estadual de Campinas, SP.

Doyle, J. A. \& Le Thomas, A. (1997). Phylogeny and geographic history of Annonaceae. Géographie physique et Quaternaire, 51(3): 353-361. doi: 10.7202/033135ar

Fries, R. E. (1937). Revision der Arten einiger Annonaceen-Gattungen IV. Acta Horti Berg, 12, 222-231.

Harris, J. G. \& Harris, M. W. (2001). Plant identification terminology: an illustrated glossary. Spring Lake: Spring Lake Publishing.

Johnson, D. M. \& N. A. Murray. (1995). Synopsis of the tribe Bocageeae (Annonaceae), with revisions of Cardiopetalum, Froesiodendron, Trigynaea, Bocagea, and Hornschuchia. Brittonia, 47(3), 248-319. doi: $10.2307 / 2807118$

Johnson, D. M. \& Murray, N. A. (2020). A revision of Xylopia L.(Annonaceae): the species of Madagascar and the Mascarene islands. Adansonia, 42(1), 1-88. doi: 10.5252/adansonia2020v42a1

Kessler, P. J. A. (1993). Annonaceae. In Kubitzki, K., Rohwer, J. G., \& Bittrich, V. (Ed.) Flowering plants: dicotyledons. Magnoliid, Hamamelid and Caryophyllid Families (Vol. 2, pp. 93-129). Springer-Verlag, Berlin Heidelberg.

Lobão, A. Q. (2017). A new species of Trigynaea (Annonaceae) endemic to the Atlantic Forest of Brazil. Phytotaxa,309(2), 193-196. doi: 10.11646/phytotaxa.309.2.13

Lobão, A. Q. \& Johnson, D. M. (2007). Xylopia decorticans (Annonaceae) a new cauliflorous species from Brazil. Contributions of the University of Michigan Herbarium, 25, 207-211. Avaible in: biodiversitylibrary.org/page/12697789

Lyra-Lemos, R. P., Mota, M. C. S., Chagas, E. C. O. \& Silva, F. C. (2010). Checklist flora de Alagoas: Angiospermas. IMA/MAC (1a ed.). Maceió.

Maas, P. J., Lubbert, Y. T., Westra, L. W. C., Verspagen, N., Rainer, H., Zamora, N. A., \& Erkens, R. H. (2019). Twelve new and exciting Annonaceae from the Neotropics. PhytoKeys, 126, 25-69. doi: 10.3897/phytokeys.126.33913

Maas, P. J., \& Westra, L. Y. T. (2003). Revision of the neotropical genus Pseudoxandra (Annonaceae). Blumea-Biodiversity, Evolution and Biogeography of Plants, 48(2): 201-259. doi: 10.3767/000651903X674955

Maas, P. J. M., van Heusden, E. C. H., Koek-Noorman, J., van Setten, A. K. \& Westra, L.Y.Th. (1986). Studies in Annonaceae VII. New species from the Neotropics and miscellaneous notes. Proceedings of the Koninklijke Nederlandse Akademie van Wetenschappen, 89, 249-278.

Maas, P. J. M., Westra, L. Y. T., \& Chatrou, L. W. (2003). Duguetia. Flora Neotropica Monograph, 88, 1-274.

Maas, P. J. M., Maas-Van de Kamer, H., Junikka, L., Mello-Silva, R. \& Rainer, H. (2001). Annonnaceae from central-eastern Brazil. Rodriguésia, 52(80): 65-98. doi: 10.1590/2175-78602001528005

Maas, P. J., Westra, L. Y., \& Vermeer, M. (2007). Revision of the neotropical genera Bocageopsis, Onychopetalum, and Unonopsis (Annonaceae). Blumea-Biodiversity, Evolution and Biogeography of Plants, 52(3), 413-554. doi: 10.3767/000651907X608909

Maas, P. J. M., Westra, L. Y. T., Guerrero, S. A., Lobão, A. Q., Scharf, U., Zamora, N. A., \& Erkens, R. H. J. (2015). Confronting a morphological nightmare: revision of the Neotropical genus Guatteria (Annonaceae). Blumea-Biodiversity, Evolution and Biogeography of Plants, 60(1-2): 1-219. doi: 10.3767/000651915X690341

Mace, G. M. (2004). The role of taxonomy in species conservation. Philosophical Transactions of the Royal Society of London. Series B: Biological Sciences, 359(1444), 711-719. doi: 10.1098/rstb.2003.1454

Nusbaumer, L., Barbosa, M. R. V., Thomas, W. W., Alves, M. V., Loizeau, P. A., \& Spichiger, R. (2015). Flora e vegetação da Reserva Biológica de Pedra Talhada. In Studer, A., Nusbaumer, L., \& Spichiger, R. (Ed.), Biodiversidade da Reserva Biológica de Pedra Talhada (Alagoas, Pernambuco - Brasil). (Vol. 68, pp: 59-121). Boissiera.

Peixoto, A. L., \& Maia, L. C. (2013). Manual de Procedimentos para Herbários. INCT-Herbário Virtual para a Flora e os Fungos. Recife: Editora Universitária UFPE.

Pontes, A. F., Barbosa, M. R. D. V., \& Maas, P. J. (2004). Flora Paraibana: Annonaceae Juss. Acta Botanica Brasilica, 18(2), 281-293. doi:
10.1590/S0102-33062004000200008

QGIS.org (2017). Geographic Information System. Open Source Geospatial Foundation Project. Avaible in: https://qgis.org

Rainer, H. \& Chatrou, L. W. (2006). AnnonBase: world species list of Annonaceae - version 1.1, 12 Oct 2006. Avaible in: https://www.sp2000.org/ http://www.annonaceae.org/frameset.html

Rizzini, C. T. (1963). Nota prévia sobre a divisão fitogeográfica (florísticosociológica) do Brasil. Revista Brasileira de Geografia, 25, 3-64.

Stull, G. W., Johnson, D. M., Murray, N. A., Couvreur, T. L. P., Reeger, J. E. \& Roy, C. M. (2017). Plastid and Seed Morphology Data Support a Revised Infrageneric Classification and an African Origin of the Pantropical Genus Xylopia (Annonaceae). Systematic Botany, 42(2), 211-225. doi: 10.1600/036364417X695484

Thiers, B. (2018) [continuously updated]. Index Herbariorum: a global directory of public herbaria ans associated staff. New York Botanical Garden's Virtual Herbarium.

License: Creative Commons CC BY 4.0

This article was published with open access for distribution under the terms of the Creative Commons Attribution License, which allows unrestricted use, distribution, and reproduction in any medium, provided the original work is properly cited. 